InOdia $\quad \begin{aligned} & \text { InMedia } \\ & \text { The French Journal of Media Studies }\end{aligned}$

8.2. $\mid 2020$

What do Pictures Do? (In)visibilizing the Subaltern

\title{
The Fugitive Gazes Back: The Photographic Performance Work of Frederick Douglass and Sojourner Truth
}

Martha J. Cutter

\section{(2) OpenEdition}

Journals

Electronic version

URL: https://journals.openedition.org/inmedia/2463

DOI: $10.4000 /$ inmedia.2463

ISSN: 2259-4728

Publisher

Center for Research on the English-Speaking World (CREW)

\section{Electronic reference}

Martha J. Cutter, "The Fugitive Gazes Back: The Photographic Performance Work of Frederick Douglass and Sojourner Truth", InMedia [Online], 8.2. | 2020, Online since 22 octobre 2021, connection on 28 juin 2022. URL: http://journals.openedition.org/inmedia/2463 ; DOI: https://doi.org/10.4000/ inmedia.2463

This text was automatically generated on 28 October 2021.

(c) InMedia 


\title{
The Fugitive Gazes Back: The Photographic Performance Work of Frederick Douglass and Sojourner Truth
}

\author{
Martha J. Cutter
}

1 Frederick Douglass was the most photographed nineteenth-century man in the United States-more photographed than even President Lincoln-yet he rarely smiled in his photographs; one goal of his photographic portraits (as I will discuss) was to counteract the image of the "content" enslaved individual that he felt was endemic within US visual culture. Sojourner Truth sold images of herself, sometimes with an intriguing motto that read: "I sell the shadow to support the substance." These individuals may have seemed to present a version of their "true self" to the US public. Yet if scrutinized closely, their photographic portraits reveal that they were visually performing versions of their identities, marketing images of themselves in US visual culture that may or may not reflect who they really "were."

2 Michel Foucault famously writes that "visibility is a trap" 1 and this is particularly accurate for individuals disempowered by race or gender. Moreover, as Nicolas Mirzoeff has argued, slavery depended on a structure in which the enslaved were symbolically deprived of the right to look and became the object of constant surveillance. ${ }^{2}$ At times, Douglass and Truth seemed skeptical of the visual realm. Therefore, they often implied that the realm of the visual had not "captured" their true selves, even as they were deadly serious in using this realm to renovate pejorative images of African Americans. Antislavery discourse, both in England and in the US, tended to rely on a visual presentation of the enslaved as abject, pitiful, tortured, and gazed upon objects, as Marcus Wood, Martha J. Cutter, Simon Gikandi, ${ }^{3}$ and others have documented. It was vital that Truth and Douglass circumvent this presentation of the enslaved or formerly enslaved individual, while also protecting their "true" selves. 
3 For these reasons, Douglass and Truth shielded their identities through a process in which an onstage, constructed visual avatar performed their self (which may have seemed real enough to the viewer). An avatar is not the real individual but a figurative representation; since 1850 the term has been used to mean a person's manifestation or display of themselves. ${ }^{4}$ By manipulating aspects of the photographic mise-en-scène such as facial expressions, props, clothing, and symbolic objects, Douglass and Truth put forward intricate avatars that allowed them to question the realm of the visual, while the "real" individual was protected and strategically invisibilized by layers of disguise, veiling, manipulation, and performance. of course, invisibilization is often theorized as a mode of disempowerment and suppression. ${ }^{5}$ But I apply a different theoretical lens here, one that is taken from Frantz Fanon and locates a mode of strategic invisibilization that allows for the manipulation of power relationships. Fanon argues that when individuals understand the ways they are perceived, as well as opportunities to make evident different aspects of their identities, they can strategically enter different levels of both visibility and invisibility to further their goals. For example, he discusses the role of the veil during the Algerian revolution, when women veiled or unveiled to avoid surveillance and suspicion, as well as to enable them to carry weapons. ${ }^{6}$ I suggest that for African Americans who have been overly visualized and scrutinized, strategic invisibilization can become a tool of social or visual power via the embodied avatar that protects them from optical scrutiny, while still forwarding vital social and political messages.

\section{Photography and Performance: Curating a "Self" Via an Embodied Avatar}

4 The works that Douglass and Truth published based on the story of their lives contained illustrated (engraved) frontispiece portraits. In the case of Douglass he struggled to control how he was represented in this medium. Indeed, Douglass hated the illustrated portrait of him that accompanied the 1845 Dublin edition of his Narrative, in part because it represented him with a slight smile; he accused the engraver of drawing him "with a more kindly and amiable expression than is generally thought to characterize the face of a fugitive." Because both Douglass and Truth were able to manipulate the photographic mise-en-scène to their own benefit in crafting identities that counteracted the dominant culture's attempt to visually construct them, I focus exclusively on photographs of them rather than on their engraved portraits.

Both individuals present in their photographic portraits a performative self, one that was highly curated and partially invisibilized through the avatars they created. I am influenced in this essay by Uri McMillan's argument that individuals can perform objecthood by deploying the tactics and aesthetics of the avatar and by B. Coleman's suggestion that avatars act as extensions of agency. ${ }^{8}$ The avatars curated by Douglass and Truth in photographs became a protective second skin that cloaked them in a certain strategic invisibility, even as they seemed to be proffering themselves to the world as true and valid representational objects. They created fugitive personae that represented them but also protected them, and often critiqued processes of visuality, of what could and could not be seen within the photographic frame. Their avatars functioned as extensions of their agency because they critiqued the dominant culture's desire for visual control and impart vital socio-political messages about US culture. 


\section{Picture Making as "Truth or Error": The Photographic Performance Work of Frederick Douglass}

6 In addition to being the most photographed US man in the nineteenth century, Douglass was a sophisticated theorist of photography; he spoke and wrote extensively about it in three lectures. In a speech that he gave in the mid-1850s, Douglass critiqued the visual portrayal of Blacks in scientific treatises about race, saying that the "Negro" is pictured "with features distorted, lips exaggerated-forehead low and depressedand the whole countenance made to harmonize with the popular idea of Negro ignorance, degradation and imbecility." As regards photography, he was more inclined to believe that it could help others see a truer (if not exactly true) reality of their image. Due to the advent of photography, he writes, "men of all conditions and classes can now see themselves as others see them and as they will be seen by those [who] shall come after them." 10

7 Scholars have argued that Douglass was one of the first individuals to use photography as a public relations instrument. ${ }^{11}$ Matthew Fox-Amato writes that Douglass understood how sitting for a photographic portrait could help him project "humanity and dignity amidst northern racism." ${ }^{12}$ Yet photography often was entwined with oppressive forces. For example, photographs of enslaved individuals were used by slaveholders to document the "beneficent" nature of slavery and even sometimes deployed in the recapture of fugitives. Douglass's relationship with the visual realm therefore was complex; he comprehended its power to project dignity for African Americans but also to caricature, surveil, and capture them.

8 Much has been written about Douglass's attitude toward photography, ${ }^{13}$ but I analyze one claim that has been made: that Douglass equated photography with truth and reality. In contradistinction to this view, I argue that Douglass comprehended that photographic portraits could be manipulated through background, lighting, facial expression, and other aspects to mediate and negotiate African American identity. He understood that the photograph was not reality but an image of reality, a sort of mold into which different versions of selfhood could be poured, a protective shell that might encase a constructed identity. Douglass's photographic avatars therefore performed resistant versions of African American selfhood and (at times) critiqued visual surveillance and the use of photography for socially progressive agendas. Over the arc of Douglass's fifty-year-long public life (1840 to 1895), he consciously brought himself back as a revenant via photography (using Laura Wexler's terms) ${ }^{14}$ from the "social death" of slavery, a state in which the enslaved was equated with property rather than humanity. Yet Douglass also stressed the limitations of the visual realm; his photographic avatar eventually reflects disillusionment not only with his country but also with the ability of photography to foster social or political change..$^{15}$

Rather than focusing on all the photographs of Douglass that exist (and the archive is vast), I discuss several that reflect, first, his articulation of himself as a subject-in-themaking; second, the creation of the heroic and at times angry avatar of abolition; third, his commentary on political struggle through the use of symbolic objects; and fourth, how his photographic avatar came to reflect disillusionment with photography during the era that historians refer to as the Nadir (roughly 1877-1901), the period of time 
after Reconstruction when the progress made for African Americans in political rights was curtailed and lynching was rampant.

In early daguerreotypes, Douglass had not yet created his most characteristic photographic avatar, one in which his expression was often filled with anger, indignation, and even scorn. Instead, he appears to perform an image of himself as a thoughtful and intellectual young man, a subject-in-the-making; such an enunciation is necessary, given that formerly enslaved individuals were not always recognized by Whites as possessing full human subjectivity and identity. Tina Campt contends that photographs that exist serially (which is the case with both Douglass and Truth, because they were repeatedly photographed) must be understood as part of a "complex processes of cultural articulation, improvisation, and reiteration. Far from constituting a replication, they are repetitions with a difference." Campt also suggests that we understand such portraits as representing "subjects in becoming" and "forms of identification and subjectivity that perhaps, at the time, had yet to be articulated." ${ }^{16} \mathrm{We}$ must therefore first carefully consider early photographs of Douglass to grasp the ways in which they present a "subject-in-the-making" that will be repeated (with some profound differences) in later sittings.

In the first known photograph of Douglass (from 1841), he directly faces the camera, which seems to illuminate his torso (head, neck, and face). Douglass had escaped from slavery in 1838, only three years earlier, and he was just becoming known for his abolitionist speaking. He was twenty-three, and still subject to re-capture by his former enslaver. Perhaps most importantly, he had not yet published the work that would make him famous and be groundbreaking for the abolitionist movement, his Narrative of the Life of Frederick Douglass, and American Slave, Written by Himself (1845) (see Figure 1):

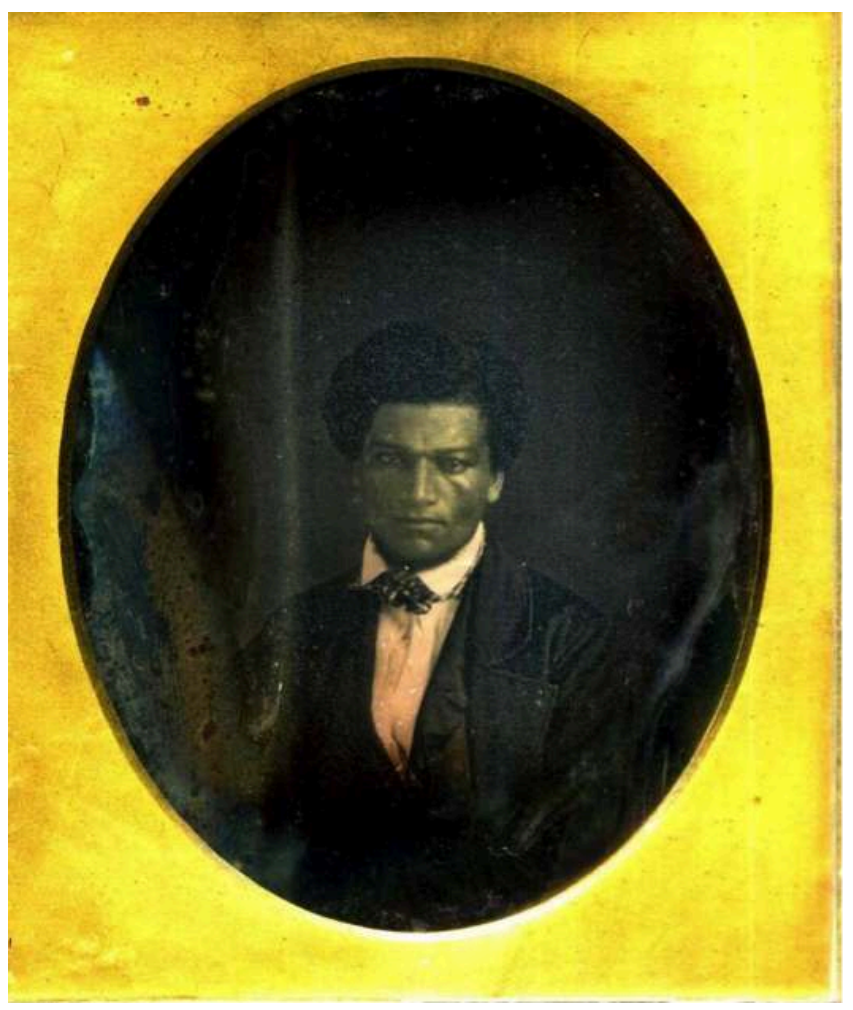


Figure 1: Daguerreotype of Frederick Douglass, ca. 1841.

This is, most likely, the earliest photographic image of Douglass. Collection of Greg French. Used with permission. high-necked white shirt, and a speckled bow tie; his hair is neatly arranged. The darkness of Douglass's suit blends into the darkness of the photograph's background, creating a chiaroscuro effect that emphasizes the light on Douglass's face and his white shirt, almost as if his head and neck were caught in a spotlight and floating in space. Such an early image guaranteed a type of authenticity and dignity to the formerly enslaved individual in the face of white racism and skepticism toward the full humanity of Blacks. Of course, as Janet Neary notes, such authenticating gestures create a paradox: the formerly enslaved individual was forced to adopt the absurd position of having to prove his or her own selfhood via the visual realm. ${ }^{17}$

In focusing on Douglass's face and head via lighting to such a large degree, the photograph highlights his intellect and intelligence. Moreover, by stressing his sophisticated and tasteful dress, especially in contrast to enslaved or formerly enslaved individuals who were pictured in their "slave outfits" or in tattered rags or little clothing, the image makes the point that this man is no longer a slave. Although he may not yet have entered the space of legal freedom, his right to such is enunciated via this respectful, careful, and conscious curation of himself as a political subject-in-themaking. His gaze meets that of the viewer squarely and seems calm and even; he does not appear to demand anything from the viewer other than that they look back at him with respect. Other photographs from this early period represent Douglass as a composed and even quiet young man who is beginning to shape a political subjectivity but has not yet created the avatar of the defiant abolitionist that would challenge the viewer more directly. ${ }^{18}$

Even in those early years, Douglass understood that if he did not direct the creation of his image, others would control it. As mentioned, he did not like the engraved frontispiece portraits in many of the early editions of his Narrative because he thought they showed him as happy or content. Therefore, it is perhaps not so startling that he eventually crafted a radically different image of himself in his photographs, beginning in 1852. In a famous daguerreotype taken in Akron, Ohio by Samuel J. Miller, Douglass maintains an expression of just-barely suppressed anger (see Figure 2). 


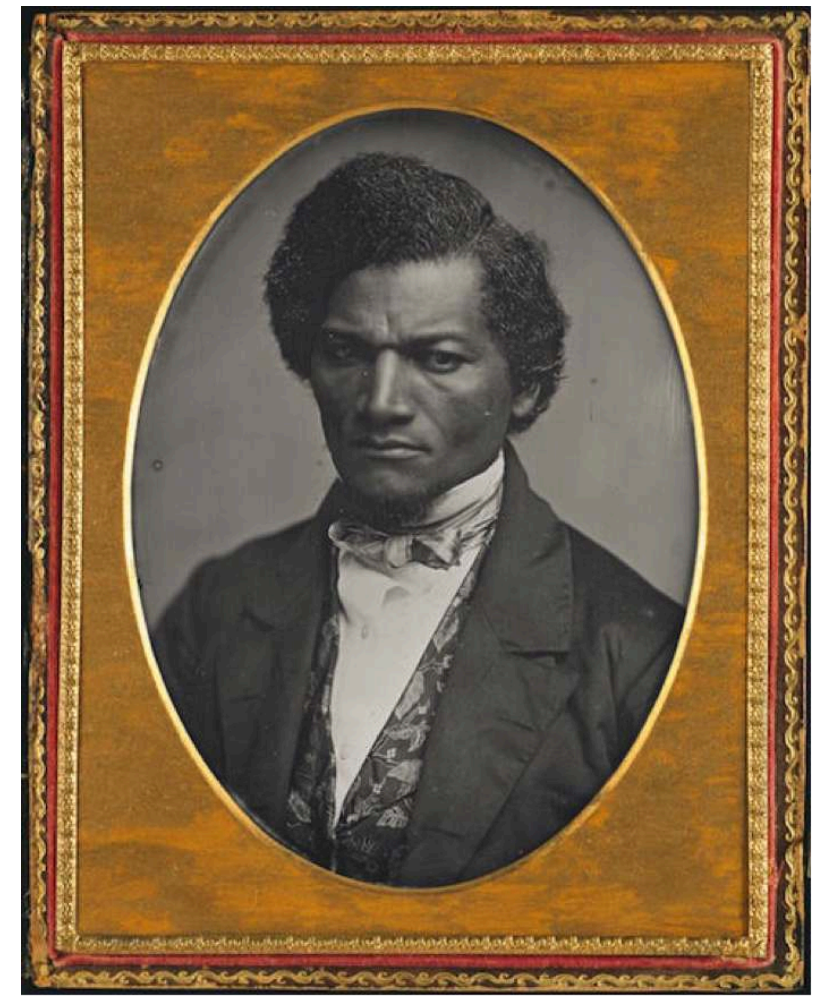

Figure 2: 1852 Daguerreotype of Frederick Douglass by Samuel J. Miller.

Chicago Art Institute. Used with permission.

Douglass is again elegantly dressed and coiffed, and he wears a stylish, richly brocaded vest. However, in this picture Douglass's torso is a bit twisted away from us and his brow is furrowed; due to this configuration, one of his eyes is in partial shadow. Perhaps the darkness that covers the right side of his face is meant to evoke those individuals who still reside in the darkness of slavery proper. Most strikingly, the calm icon of Douglass in the prior photograph is gone. Douglass now performs a type of righteous indignation-his brows are furrowed, his eyes focused, and his mouth is set gravely-as he attempts to galvanize the viewer into action.

Douglass understood how to sit for a daguerreotype, and he could certainly have chosen any number of expressions to manifest such as sadness, pain, or stoicism. Yet he consciously selected an expression of ire, one which he would replicate in at least seven other photographs taken in the 1850s and early $1860 \mathrm{~s} .{ }^{19} \mathrm{He}$ ran the risk of reifying white stereotypes of African Americans' violence and brutality; his stylish clothing enunciates African American civility, yet his expression of anger was in some ways a risky choice. In this period, the process of taking the daguerreotype had become swifter, but subjects needed to hold a pose perfectly still for twenty to sixty seconds for the image to be clear rather than blurry. Douglass carefully selected the photographers with whom he would work, adopting an active rather than a passive relationship with them, leading Celeste-Marie Bernier and Bill Lawson to argue that in his photographic portraits he assumed the role of a "performer and trickster." ${ }^{20}$ So it is important to consider what Douglass's choice to present anger and indignation in front of the camera might be saying, and to whom he might be saying it. 
17 Ariella Azoulay writes that in photographs a civil contract exists that "enables the injured parties to present their grievances, in person or through others, now or in the future." ${ }^{21}$ In this photograph, Douglass's angry avatar may have been presenting grievances about the country's lack of progress in abolishing slavery and may have been attempting to create a community in which spectatorship might foster human rights. Just about one month before this photograph was taken, Douglass had delivered his famous and scathing speech, "What to the Slave is the Fourth of July?" The speech is fiery, and the above avatar channels Douglass's performance of anger at his country for not making better progress toward emancipation. ${ }^{22}$ Most vitally, the 1852 portrait functions as a mode of strategic invisibilization that might enable activism on the part of the viewer; we do not know if the angry activist avatar he manifests reflects his true sentiments, but it does present a mode for the fomentation of political change via his indignation, which might have been transferred to the viewer.

In "Pictures and Progress," Douglass says that man is the "only picture-making animal" ${ }^{23}$-which has been taken to mean that humans are the only animal with the desire to replicate the world visually or images of themselves. But if we think of this phrase more symbolically, it can also mean that humans are the only animals with the desire to shape, create, and reconstruct reality, which we see Douglass attempting to do in the above photograph via his avatar's indignation, which he hoped to transmit to the viewer. Douglass also stated that the "picture-making faculty" was "capable of being harnessed to the car of truth or error: It is a vast power to whatever cause it is coupled." ${ }^{24}$ This statement relates to pictures of all kinds, including photographs, which would be harnessed either to "truth" or "error." of course, this statement does not mean that Douglass believed any one photograph or other visual media could convey the entire truth of his (or any person's) life, but it does imply that he believed pictures could move a viewer along a spectrum, away from mistruths (such as the idea of his race as debased or servile) and towards certain kinds of truths (such as the agency and self-possession of formerly enslaved individuals) via their manipulation and staging.

Like the above photograph, several of the portraits of Douglass from the mid-1850s staged an image of Douglass as an angry, determined advocate for abolition; indeed, this angry, defiant image would be frequently replicated..$^{25}$ Photographs taken after the Civil War, however, suggest a movement into a performance as an elder statesman with long-term political goals such as a critique of the nation's progressive agenda. In one of these photographs, Douglass poses with a highly symbolic item-the cane of the (now dead) Abraham Lincoln. The cane is gripped in his two hands at the bottom of the picture (see Figure 3). 


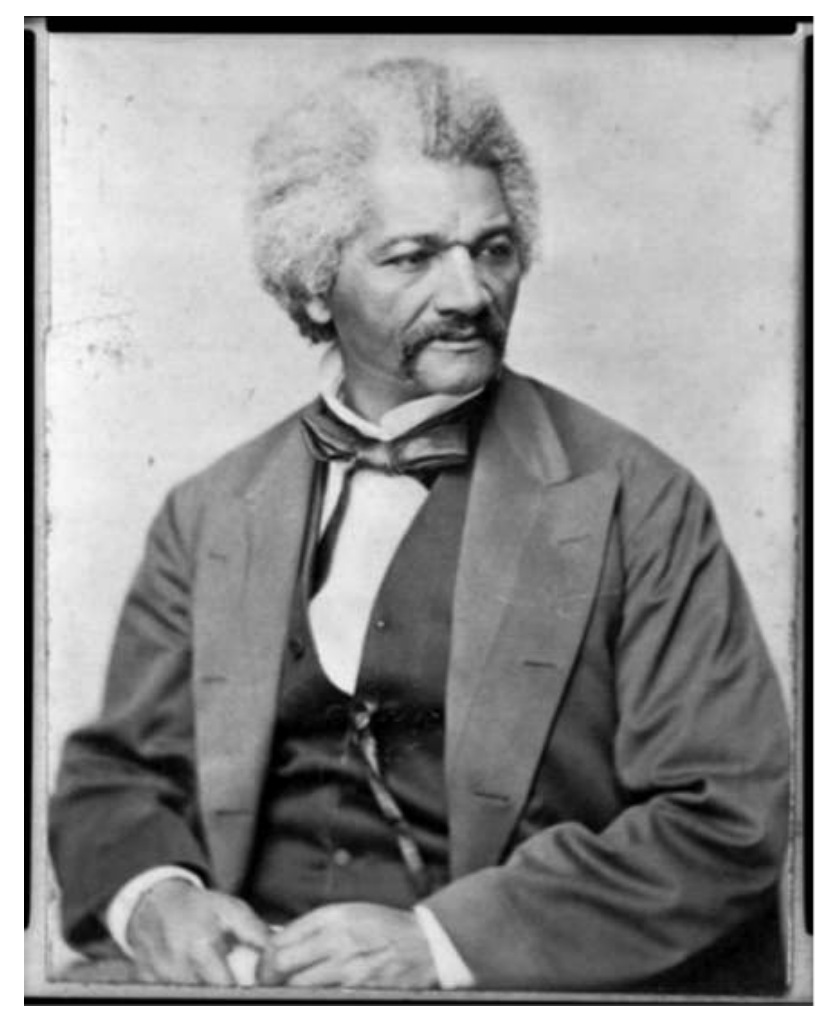

Figure 3: Frederick Douglass sits for a portrait in April 1870, George Francis Schreiber

Library of Congress, https://www.loc.gov/pictures/item/2004671911/. In his hands he holds the top of Lincoln's cane.

After Lincoln was assassinated in 1865, his widow, Mary Todd Lincoln, gave Douglass the cane. It is, of course, an item fraught with historical and symbolic significance. Yet perhaps the most unusual aspect is that the cane-which had a long and ornate gold shaft-is buried in Douglass's hands and can barely be seen. This photograph was used on a carte-de-visite that would circulate widely, and Douglass could have made more of the fact that he possessed Lincoln's cane and was proud of it; instead, the gift is a sort of absent presence in the photograph, at the bottommost edge. Douglass looks off over his left shoulder, with a pronounced turn of his head away from Lincoln's cane. Why is the cane so suppressed within the visual frame?

Azoulay explains that photography is much more than what is printed on photographic paper: "the photograph bears the seal of the event itself, and reconstructing that event requires more than just identifying what is shown in the photograph. One needs to stop looking at the photograph and instead start watching it." ${ }^{26}$ So if we watch Douglass holding Lincoln's cane in his hand and looking away from it, we find a trace of not only what is seen but what lies below the photographic surface. An address that Douglass gave six years later (in 1876) may offer some insight into his thoughts on the legacy of Lincoln. This speech was crafted for the unveiling of a monument dedicated to Lincoln as the "Great Emancipator"; the monument shows Lincoln freeing a kneeling, shackled, enslaved man. Douglass states: "truth compels me to admit ... [Abraham Lincoln] was preeminently the white man's president. . . . He was ready and willing at any time during the first years of his administration to deny, postpone, and sacrifice the rights of humanity in the colored people to promote the welfare of the white people of the country." Indeed, during the Secession crisis of 1860-61 and continuing into 1862, 
Lincoln supported protections for slavery in southern states; he was "willing to pursue, recapture, and send back the fugitive slave to his master." In 1862 Lincoln met with five Black ministers at the White House and told them "strangely ... to leave the land in which we were born." He told this group that he would "save the Union with slavery"; in other words, he was not (at this juncture) for the abolition of slavery. ${ }^{27}$ Douglass's views on the "Great Emancipator" were filled with a sense that Lincoln was not always or primarily a true hero to African Americans, but more of an accidental one.

In his photograph with Lincoln's cane, Douglass tries to put this paradoxical relationship into play through his positioning of Lincoln's cane and the space devoted (or rather not devoted) to the cane itself. If photography is, as Roland Barthes argues, "a kind of primitive theater," ${ }^{28}$ we must consider what the "prop" of Lincoln's cane symbolizes in the photograph. The absent presence of Lincoln's cane may ask viewers to meditate carefully and even skeptically on Lincoln's legacy and achievements. In this photograph, Douglass's eyes also do not meet the viewer's and have a far-off look to them. Viewers of the photograph can watch Douglass's avatar looking away from the past (Lincoln's cane) and into a possible future but not seeing anything particularly hopeful there; it is as if neither past not future give him any comfort. Given that 1876 (six years after this photograph was taken) would mark the end of Reconstruction, this performance of pessimism and wariness was justified. Yet we may also consider this a mode of strategic invisibilization because the avatar's posing with the absent presence of Lincoln's cane was staged in such a way that it both reveals and conceals Douglass's true sentiments about the legacy of the former president.

Toward the end of his life, Douglass may have also become pessimistic about photography, using strategic invisibility and his embodied avatar to reflect negativity about the nation's progress and his own use of the visual realm to instigate political change. In a photograph from 1893 taken at his home (Cedar Hill) in Washington, DC, he almost seems to be hiding from the camera and from viewers (see Figure 4).

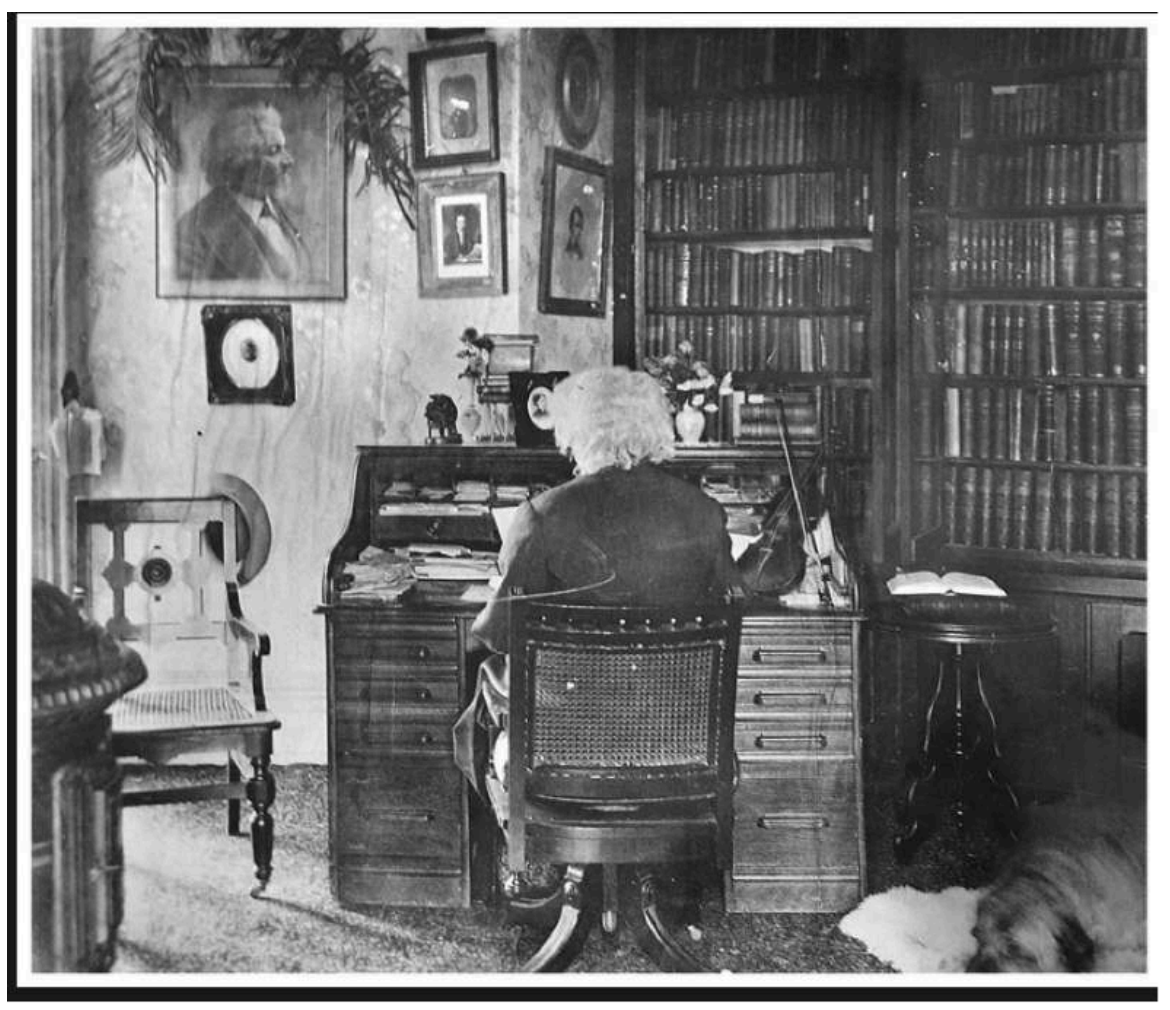


Figure 4: Frederick Douglass at his home in Washington, DC, 1893.

Moorland-Spingarn Research Center, Howard University Archives, Howard University, Washington, DC. consider the import of Douglass's turned back and his disregard for the camera and the viewer. Shawn Michelle Smith writes that African Americans used photography to declare their status as subjects; she notes that even as such portraits objectify individuals, these visual works allow them to see themselves in unique ways. About Douglass, she notes that the objectification proffered through representation, and especially through photography, "was a necessary foundation for self-evaluation and critique, which in turn provided the basis for social progress." ${ }^{29}$ Yet perhaps by the 1890s, Douglass felt that he needed to turn away from the idea of using photography to advance human or civil rights and social progress. At this point the US had entered the Nadir-the worst period in US history for African Americans in terms of lynching, other acts of illegal violence, the institutionalization of Jim Crow segregation, and the removal of many of the voting reforms put in place during Reconstruction. In the 1893 photo, Douglass created an avatar who may perform negativity toward the idea that African Americans would ever have full citizenship. The turned back strategically invisibilizes the "real" Frederick Douglass and presents instead an avatar who stages cynicism toward the idea of deploying the visual as a domain that could enact lasting psychological or political change or create a virtual community of spectators.

Thirty years earlier, in a speech called "Age of Pictures" (1862), Douglass said, "There is a prophet within us, forever whispering that behind the seen lies the immeasurable unseen." ${ }^{30}$ In photographs in which Douglass does not face the camera (and there is at least one other from this era, where Douglass looks down at his desk rather than out at the viewer), ${ }^{31}$ he gestures to the "immeasurable unseen" that lies under or behind the photographic surface, or perhaps beyond the photographic trace. In other words, he inscribes what cannot be caught within this highly visual realm. This 1893 photograph encourages a viewer to consider what is left uncaptured by visual images and grants Douglass a certain protective concealment. In this sense, this last picture epitomizes a fit ending for a discussion of Douglass's use of photography as a mode of performance and socio-political change. Whereas earlier his avatar had staged righteous anger via expressions and political critique via symbolic objects, here the avatar turns away from the camera. In so doing, Douglass speaks to what is outside or beyond the photograph, which in this case might be a future where he no longer must perpetually authorize and perform his selfhood via the visual realm, embodied avatars, and modes of strategic invisibilization. 


\section{Selling "The Shadow": The Photographic Performance Work of Sojourner Truth}

Truth's photographs also create performative avatars that grant her a degree of strategic invisibility within the folds of the guises she wears; these images critique society and delineate limitations of the visual realm as an instrument of selfempowerment. Her pictures gestured to time and the unseen realm (the shadow world) even as they created a space for her self-representations within living memory. As mentioned, many of her portraits and photographs appeared with the motto: "I sell the shadow to support the substance." But before unpacking this phrase, we must consider earlier illustrations in which this phrase did not appear, and in which Truth let others stage-manage how her picture was created. These earlier instances of having someone visually construct her may have led to a desire to perform her images more overtly in later photographs, which she asserted not only in her motto, but also by the insertion of highly allegorical objects into the visual frame.

Like Douglass, Truth comprehended that illustrations and photographs could be manipulated, that they could betray the person whose image was being captured, and she understood that visuality could turn her into a spectacle. In the earliest known photograph of Truth-an uncaptioned carte-de-visite that can be dated to the start of the Civil War, likely 1861-she becomes an object at which viewers might gawk, rather than the conscious producer of her own visual presence (see Figure 5).

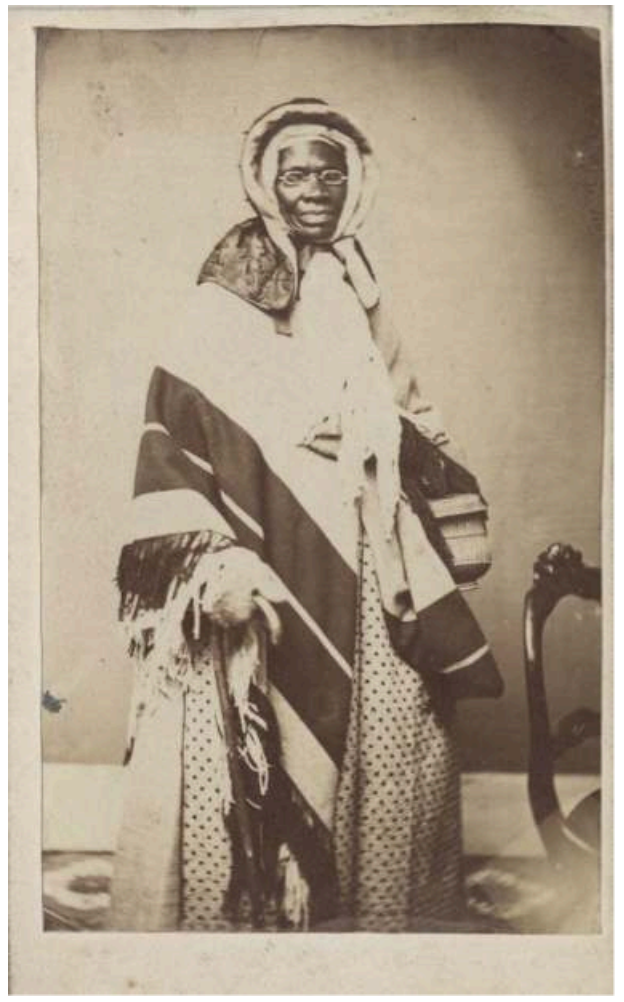

Figure 5: Carte-de-visite of Sojourner Truth, likely from 1861.

Used with permission, courtesy of Chicago History Museum.

Azoulay argues that, when possible, the situation from which a photograph was taken should be reconstructed. ${ }^{32}$ The unusual and dramatic circumstances surrounding the 
creation of this photograph have been recorded. In June of 1861, Truth was giving a speech to a hostile, pro-slavery crowd in Angola, Indiana. Her supporters took it upon themselves to gird her for the battle, as she relates in the 1875 updating of Narrative of Sojourner Truth (originally published in 1850):

The ladies thought I should be dressed in uniform. ... So, they put upon me a red, white, and blue shawl, a sash and apron to match, a cap on my head with a star in front, and a star on each shoulder. When I was dressed I looked in the glass and was fairly frightened. Said I, "It seems I am going to battle." My friends advised me to take a sword or pistol. I replied, "I carry no weapon; the Lord will reserve [preserve] me without weapons. I feel safe even in the midst of my enemies; for the truth is powerful and will prevail." ${ }^{33}$

Truth had to be escorted by a military guard to her speaking engagement; along the way individuals called her vile racial slurs. To "prepare" her for this, the ladies dressed her in strange clothing; she makes clear that she does not need these accoutrements and even refuses a gun, ironically playing with her own name: "The Lord will reserve [preserve] me... . The truth is powerful and will prevail." In this photograph Truth is, as Darcy Grimaldo Grigsby puts it, "all but overwhelmed by clothing and accessories"; she is covered by layers of fabric and in what seems to be a "theatrical, enveloping costume." ${ }^{34}$ Yet this clothing was not her choice and did not reflect the way Truth wanted to present herself. Certainly, no photograph is entirely liberatory, and images often contain a play between self-fashioning and subjugation, but this image seems to slide Truth into the realm of a captured entity fashioned by others.

For Truth, this instance of being costumed against her will may have functioned as a sort of cautionary lesson. In her later photographs she develops a subtler visual persona, one with multiple messages and enigmatic meanings. Truth raised money by selling her photographs, and she had as many as fourteen photographic portraits made in at least seven different sittings. Yet she was not merely making money from these photographs. As Nell Irvin Painter further reminds us, Truth could have taken advantage of the craze for battered, formerly enslaved bodies by exhibiting her right hand, which had been maimed while she was enslaved. ${ }^{35}$ Instead she chose to include other details to stage-manage herself and create avatars that might contradict this trend; such visual personae also strategically invisibilize her by partially veiling her body and controversial ideas.

Two types of photographs illustrate how Truth developed an understated photographic avatar in later images that redeployed relations of power in unexpected ways via strategic invisibilization. The first type of photograph references visuality by including other photographs within the frame. In one set of images, she is pictured with a small daguerreotype of her grandson James Caldwell, who was a prisoner of war at James Island, in South Carolina. These photographs were taken in 1863 and there are at least four of them, with Truth in different poses. Yet in each, the daguerreotype of James rests carefully in her lap (see Figure 6). 


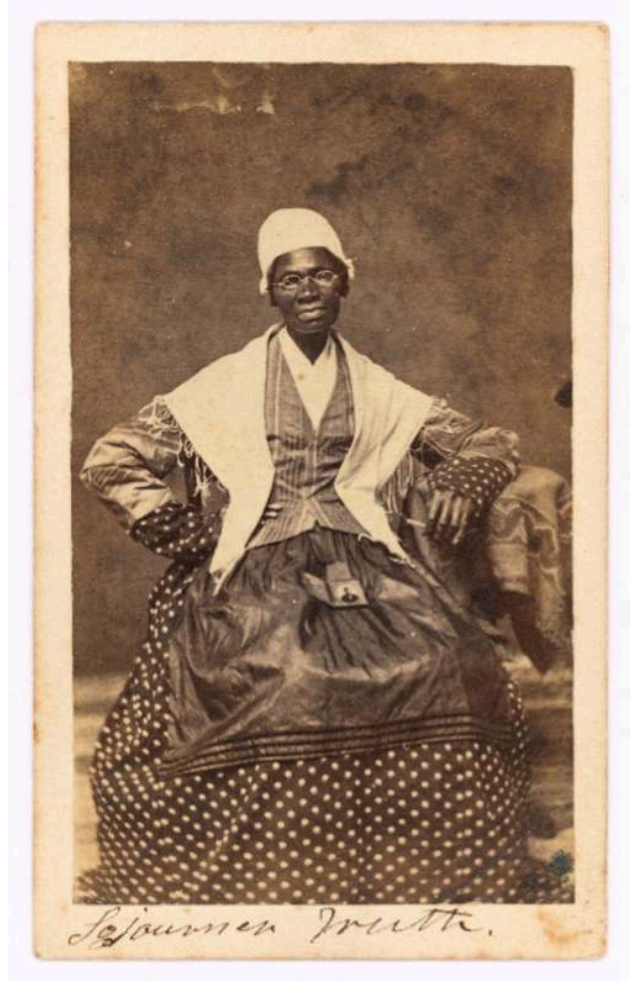

Figure 6: Carte-de-visite of Sojourner Truth with a photograph of her grandson, James Caldwell, on her lap, ca. 1863-1865

Library of Congress. https://www.loc.gov/pictures/item/2017648645/

Truth's visual avatar confronts viewers directly, looking into their faces. By looking back at the viewer, she may try to implicate readers into a civil contract which assumes the existence of a hypothetical spectator who could be moved towards indignation or anger by images. In discussing photographs in which the subject looks at the viewer, Azoulay argues that such images may formulate a series of questions: "Why are these men, women, children, and families looking at me? . . At whom, precisely, did they seek to look-was it truly at me? And why? What am I supposed to do with their look? What is the foundation of the gaze I might turn back toward them?" ${ }^{36}$ She argues that this looking may gesture towards a realm in which relationships between the viewed and the viewer are not mediated by the dominant power but by a type of civil contract that imagines a new conceptual framework of partnership and solidarity between the oppressed and the viewer. This may be a virtual or symbolic partnership (rather than an actual and localized one) but given that Truth's avatar turns her gaze directly on the viewer, her text may be gesturing to a hypothetical community of viewers who can understand the political content of this gesture and respond to it with something like solidarity. Truth may have lost a grandson (at this time, she did not know where he was; he had been captured by rebel soldiers and would survive, but Truth only knew that he was missing). Her avatar's look at the viewer may have been asking them to understand her sacrifice for her country and to extend political and human rights not only to him, but also to her.

Moreover, Truth's inclusion of a grandson who was fighting on the Union side demands a type of recognition of his symbolic citizenship. In this era, some abolitionists argued that once freed, all African American men should have full citizenship rights, including 
the vote, but Lincoln had not yet acquiesced to this idea. Truth's photograph attests to her feelings on this subject-if her grandson could fight in the war, he deserved inclusion in the nation as a full citizen. Campt contends that photographs of African Americans place people historically and socially by articulating "a profound aspiration to forms of national and cultural belonging, inclusion, and social status. ${ }^{37}$ We can see Truth's inclusion of this photograph, then, as her staging of an aspiration towards Black citizenship for her grandson that might even drift into her own enunciation of citizenship rights, at least within a virtual or symbolic social community. Azoulay writes that women's citizenship status is impaired under most forms of rule, but also that "when an injured person tries to address others through a photograph, she is becoming a citizen in the citizenry of photography." 38 If citizenship rights could be extended to her grandson, might they also one day be extended to her and other Black women? In other words, the "citizenship of photography" might eventually extend out from the photograph to society.

The picture-within-the-picture of her grandson also spoke to contemporaneous conflicts about the status and treatment of Black soldiers. African Americans who fought for the Union were underpaid, denied commissions, and often had to endure racist violence; in addition, they suffered an astronomically high rate of death due to the dangerous missions they were given, poor health facilities, and deplorable living conditions in their encampments. If we watch this photograph carefully and investigate the picture within-the-picture, then, we can see Truth's avatar reminding viewers of these facts. This small detail or prop is part of the larger political story and context of the picture as a whole-a historical context in which the service of Black soldiers to the Union demanded greater recognition. Yet this was a very subtle visual language, one which protected Truth and may have even shielded her from political attacks by those who did not agree with her ideas.

As with Douglass, props within the photograph point shrewdly towards larger political questions and debates. In this regard, a series of portraits in which her photographic avatar knits is particularly intriguing. Truth liked to knit and had taught other women this skill; knitting was also an element of middle-class femininity and domesticity and has been interpreted as an aspect of her motherliness. ${ }^{39}$ Knitting therefore represents Truth's public performance of a status denied to Black women, who were often configured in the public imagination in the nineteenth century as slaves or servants. In photographs where Truth's avatar knits, she is usually surrounded by other accoutrements of domesticity, such as books, flowers, and a white shawl and cap (see Figure 7). 


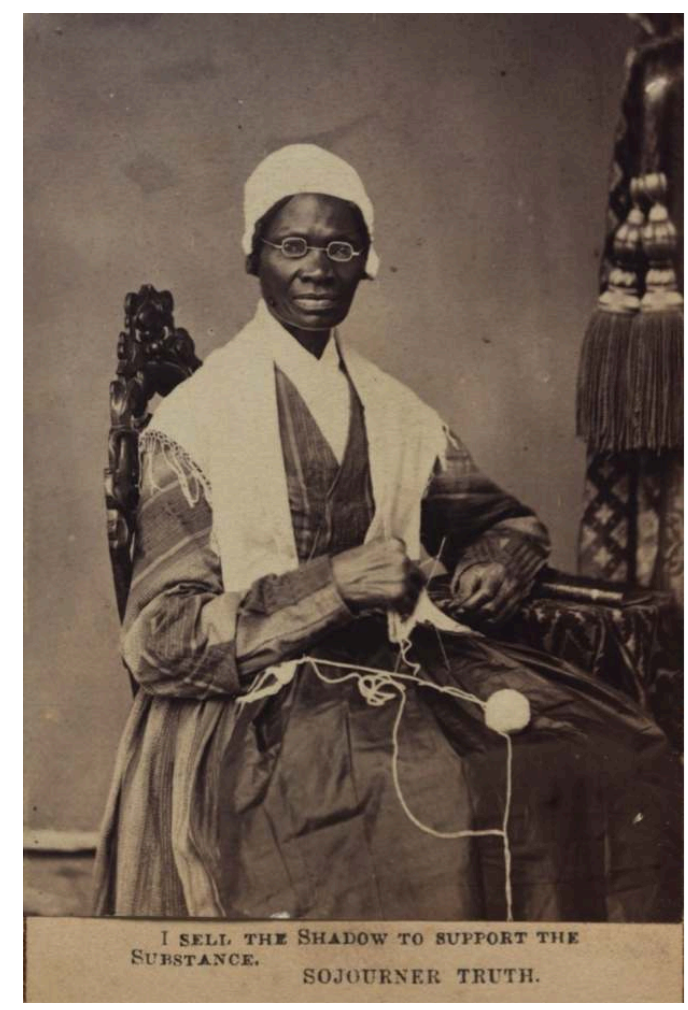

Figure 7: Photograph of Sojourner Truth, 1865

Albumen silver print; National Portrait Gallery, Smithsonian Institution carved chair and there are heavy draperies in the right-hand side of the picture, symbols of middle-class gentility. She wears glasses which perhaps to some degree shield her eyes from a direct gaze by the viewer, but she looks at us with a slight tilt to her head. In this photograph, Truth's persona appears to gaze back at a viewer with a direct look that grants her a degree of resistance to being merely the object of a white gaze.

Yet what happens if we watch Truth's avatar knitting in this photograph as an active performance, rather than seeing it as only a static event? What we might notice when we watch the photograph is that that the ball of yarn is twisted into a tangle and even into the fringes of her shawl; it would not feed easily into her knitting needles. The detail of the twisted yarn is repeated in many of the photographs from this era, so what might it symbolize? ${ }^{40}$ Given the date (1864-1865), the Union had already been unraveling for several years (since 1861) because of the Civil War. Moreover, in the last few years of the war, heated debates disrupted Lincoln's Republican Party and the nation over the status of African American Civil War soldiers who served under horrific conditions, as previously mentioned. Beyond this, there was great conflict over the status of formerly enslaved individuals (in states in the South that the North had taken), with some politicians suggesting that they could go free and others (horrifically) that they stay with their enslavers until the conclusion of the war. Debates about colonization-the idea of sending former slaves to Africa, which Lincoln at the time endorsed-also agitated the nation. The messy yarn in Truth's photographs may allude to questions about whether the nation, now unraveled by war and 
controversy, could ever be knit back together. Moreover, such photographs, if taken after Lincoln's death on April 15, 1865, could also allude to fear for the safety of the nation under the disastrous presidency of Lincoln's vice president, Andrew Johnson, an avowed white supremacist. In photographs of Truth from long after the war and Johnson's presidency, taken for example in the 1880s, the unspooled yarn is absent, although we do see the seated pose, elaborate accoutrements of middle-class domesticity, and Truth's motto. ${ }^{41}$

Like the unraveling ball of yarn, there is also a symbolic and metaphorical quality to the caption on the photograph. Theorists of visual media argue that captions on illustrations function like author's voice-overs: they usually encourage a particular interpretation of a picture. ${ }^{42}$ But Truth's motto ("I sell the shadow to support the substance") may not push forward a specific conceptualization of her image; it may perhaps instead propose a series of topics to ponder. The most overt reading is that she sells a simulacrum of herself-the photograph-to support the substance (the internal self or soul). Yet other critics argue that because in religious contexts (with which Truth was very familiar) the shadow was associated with the soul (not the body), Truth could be making the point that she is selling her soul to support her physical self (her body). ${ }^{43}$ Still others have postulated that Truth implies that she sells her external (Black) self, which is a shadow of her true essence, to support her real internal identity. Truth therefore engages in a "race trade" in which images of herself became marketable items, things that could be bought and sold. ${ }^{44}$ But this phrase is opaque, and we must remember that in the end she sells a photograph of herself, or of something viewers assume is her "real" self; she plays with the idea that people believe they own other people, either by way of slavery or photography. Visibility may sometimes be a trap, but her motto complicates this idea by implying that the "real" Truth (the substance of her identity) is not caught in her photographs; her real self exists somewhere beyond, or perhaps outside of, this visual space. She pushes a viewer who owns or views one of these cartes-de-visite to contemplate the relationship between the self pictured and the internal person, between soul and body, shadow and substance, "reality" and a representation of reality. The photograph and its motto therefore strategically invisibilize her in a way that gives her power over the conditions of her own visuality.

Painter has argued that Truth used photography to "present the images of herself that she wanted remembered." 45 Yet something more complicated occurs when we contemplate this caption and even listen to it. Fred Moten asks us to engage in forms of looking that pay attention to the whole sensual ensemble of what is looked at because the meaning of a photograph is sometimes "cut and augmented by a sound or noise that surrounds or pierces its frame." ${ }^{46}$ If we really try to hear the motto in our heads, it may cut or interfere with the smooth processing or enjoyment of her picture, creating a type of noisy static that distorts an easy reading of her image and invisibilizes her "true identity." The bold, blocky, capitalized letters of the caption are spatially set between the image of Truth and Truth's name, as a possible bar or barrier to connecting the two unambiguously; these words are visual (we see them as they comment on the picture), linguistic (being written in language), and auditory (if we hear them). By operating on so many different registers of sight and sound, the motto critiques a reader's desire for visual or racial certainty and complicates an easy processing of this image. As viewers ponder the domain of shadow and substance, they are forced to reflect more on the subtle and covert meaning of photography-what it 
captures, and what it leaves unspoken and ambiguous-via the motto and its multiple meanings within the frame of the image.

\section{Conclusion}

Both Douglass and Truth manipulated the visual realm in their photographic portraits, creating embodied avatars that they performed and staged. They are canny in their use of modes of masking to veil and strategically invisibilize their identities, while forwarding resistant messages about whether the viewer can grasp their "true" selves. of course, Douglass and Truth utilized their photographs to demand recognition of their personhood, dignity, and symbolic citizenship, and they also laced their photographs with political messages. Yet more subversively, they deployed them to enact or perform various versions of themselves, avatars that shielded the "real" individual from full view and cloaked them in a protective layer of strategic invisibility. And they questioned the power of visual forms to contain them via references to what photography does not capture, what lies unseen, behind, or beyond the photographic surface.

Photographs of all kinds were deployed by White abolitionists to protest slavery, but many symbolically re-enslaved the individuals depicted. ${ }^{47}$ In Douglass's and Truth's photographs there is resistance to symbolic re-enslavement within images and a powerful use of strategic invisibilization to move into diverse planes of both visibility and invisibility to advance their political and social messages. Photography itself becomes a way to query photographic representation and gesture to new forms of partnership with a spectator that might be more imagined than real. Neither Douglass nor Truth were precisely caught by photographs of them. Instead, if we watch these photographic avatars carefully, they may exist for the viewer somewhere between shadow and substance, between the real world in which these individuals were still disenfranchised and a more symbolic or even virtual world where their human and civil rights have been recognized, if not yet enacted.

\section{BIBLIOGRAPHY}

Azoulay, Ariella. The Civil Contract of Photography. New York: Zone, 2008.

Barthes, Roland. Camera Lucida: Reflections on Photography. Translated by Richard Howard. New York: Hill and Wang, 2010.

Bernier, Celeste-Marie, and Bill E. Lawson. Introduction. In Pictures and Power, edited by Bernier and Lawson, 1-40.

-----, eds. Pictures and Power: Imaging and Imagining Frederick Douglass (1818-2018). Liverpool: Liverpool University Press, 2017.

Blight, David W. Frederick Douglass: Prophet of Freedom. New York: Simon \& Schuster, 2018. 
Campt, Tina. Image Matters: Archive, Photography, and the African Diaspora in Europe. Durham: Duke University Press, 2012.

Coleman, B. Hello Avatar: Rise of the Networked Generation. Cambridge, MA: MIT Press, 2011.

Cutter, Martha J. The Illustrated Slave: Empathy, Graphic Narrative, and the Visual Culture of the Transatlantic Abolition Movement, 1800-1852. Athens: University of Georgia Press, 2017.

Diamond, Elin. Introduction. In Performance and Cultural Politics, edited by Diamond, 1-14. London: Routledge, 1996.

Douglass, Frederick. “Age of Pictures” (1862). In Picturing Frederick Douglass, edited by Stauffer et al., 142-160.

----. "The Meaning of July Fourth for the Negro. A speech given at Rochester, New York, July 5, 1852." https://masshumanities.org/wp-content/uploads/2019/10/speech_complete.pdf $<$ accessed on July $21,2020>$.

-----. My Bondage and My Freedom (1855). https://docsouth.unc.edu/neh/douglass55/ douglass55.html <accessed on July 21, 2020>.

----. “The Negro as a Man.” Unpublished manuscript, ca. mid-1850s, Frederick Douglass Papers, Library of Congress, page 23, https://www.loc.gov/item/mfd.31025/ <accessed on July 20, 2020>.

-----. "Pictures and Progress." Ca. 1864-1865. In Picturing Frederick Douglass, edited by Stauffer et al., 161-73.

-----. Review of A Tribute to the Negro. The North Star April 7, 1849. African American Newspapers, Accessible Archive, www.accessible-archives.com <accessed on July 20, 2020>.

Fanon, Frantz. A Dying Colonialism, trans. translated Haakon Chevalier. New York: Grove Press, 1965.

Foucault, Michel. Discipline and Punish. Translated by Alan Sheridan. New York: Vintage, 1995. Gikandi, Simon. Slavery and the Culture of Taste. Princeton: Princeton University Press, 2011.

Fox-Amato, Matthew. Exposing Slavery: Photography, Human Bondage, and the Birth of Modern Visual Politics in America. New York: Oxford University Press, 2019.

Grigsby, Darcy Grimaldo. Enduring Truths: Sojourner's Shadows and Substance. Chicago: University of Chicago Press, 2015.

Groensteen, Thierry. The System of Comics. Translated by Bart Beaty and Nick Nguyen. Jackson: University of Mississippi Press, 2007 [1999].

Herzog, Benno. "Invisibilization and Silencing as an Ethical and Sociological Challenge." Social Epistemology 32, No. 1 (2018): 13-23.

Hill, Ginger. “'Rightly Viewed': Theorization of Self in Frederick Douglass's Lectures on Pictures.” In Pictures and Progress, edited by Wallace and Smith, 41-80.

McMillan, Uri. Embodied Avatars: Genealogies of Black Feminist Art and Performance. New York: NYU Press, 2015.

Mirzoeff, Nicholas. The Right to Look: A Counterhistory of Visuality. Durham: Duke University Press, 2011.

Moten, Fred. In the Break: The Aesthetics of the Black Radical Tradition. Minneapolis: University of Minnesota Press, 2003. 
Neary, Janet. Fugitive Testimony: On the Visual Logic of Slave Narratives. New York: Fordham University Press, 2016.

Painter, Nell Irvin. "Representing Truth: Sojourner Truth's Knowing and Becoming Known." Journal of American History 81, No. 2 (1994): 461-92.

Rohrbach, Augusta. "Shadow and Substance: Sojourner Truth in Black and White," in Pictures and Progress, edited by Wallace and Smith, 83-99.

Smith, Shawn Michelle. At the Edge of Sight: Photography and the Unseen. Durham: Duke University Press, 2013.

Stauffer, John, Zoe Trodd, and Celeste-Marie Bernier. Introduction. In Picturing Frederick Douglass, edited by Stauffer et al., i-xxviii.

-----, eds. Picturing Frederick Douglass: An Illustrated Biography of the Nineteenth Century's Most Photographed Man. New York: Liveright, 2015.

Truth, Sojourner. Narrative of Sojourner Truth; a Bondswoman of Olden Time, Emancipated by the New York Legislature in the Early Part of the Present Century; with a History of Her Labors and Correspondence, Drawn from Her "Book of Life" (Boston: 1875), 140-41, Internet Archive, https:// archive.org/details/narrativeofsojou7231gilb <accessed on July 20, 2020>.

Wallace, Maurice O. and Shawn Michelle Smith, eds. Pictures and Progress: Early Photography and the Making of African American Identity. Durham: Duke University Press, 2012.

Wexler, Laura. “'A More Perfect Likeness': Frederick Douglass and the Image of the Nation.” In Pictures and Progress, edited by Wallace and Smith, 18-39.

Wood, Marcus. Blind Memory: Visual Representation of Slavery in England and America, 1780-1865. New York: Routledge, 2000.

\section{NOTES}

1. Michel Foucault, Discipline and Punish, trans. Alan Sheridan (New York: Vintage, 1995), 200.

2. Nicholas Mirzoeff, The Right to Look: A Counterhistory of Visuality (Durham: Duke University Press, 2011): 481-83.

3. See Martha J. Cutter, The Illustrated Slave: Empathy, Graphic Narrative, and the Visual Culture of the Transatlantic Abolition Movement, 1800-1852 (Athens: University of Georgia Press, 2017), Marcus Wood, Blind Memory: Visual Representation of Slavery in England and America, 1780-1865 (New York: Routledge, 2000), and Simon Gikandi, Slavery and the Culture of Taste (Princeton: Princeton University Press, 2011).

4. See "Avatar, n.," OED Online, Oxford University Press, http://www.oed.com/view/Entry/13624 $<$ accessed July 21, 2020>.

5. For a discussion of invisibilization as disempowering, see Benno Herzog, "Invisibilization and Silencing as an Ethical and Sociological Challenge," Social Epistemology 32, No. 1 (2018): 13-23.

6. Frantz Fanon, A Dying Colonialism, trans. Haakon Chevalier (New York: Grove Press, 1965), 44-45, 59-63.

7. Frederick Douglass, Review of A Tribute to the Negro, The North Star April 7, 1849, African American Newspapers, Accessible Archive, www.accessible-archives.com <accessed July 20, 2020>.

8. Uri McMillan, Embodied Avatars: Genealogies of Black Feminist Art and Performance (New York: NYU Press, 2015), 11; B. Coleman, Hello Avatar: Rise of the Networked Generation (Cambridge, MA: MIT Press, 2011), 4. 
9. "The Negro as a Man," unpublished manuscript, ca. mid-1850s, Frederick Douglass Papers, Library of Congress, manuscript page 23, https://www.loc.gov/item/mfd.31025 <accessed July 21, 2020>.

10. Douglass, "Pictures and Progress," in Picturing Frederick Douglass: An Illustrated Biography of the Nineteenth Century's Most Photographed Man, ed. John Stauffer, Zoe Trodd, and Celeste-Marie Bernier (New York: Liveright, 2015), 165.

11. Stauffer, Trodd, and Bernier, Introduction to Picturing Frederick Douglass, i-xxviii.

12. Matthew Fox-Amato, Exposing Slavery: Photography, Human Bondage, and the Birth of Modern Visual Politics in America (New York: Oxford University Press, 2019), 2 and 21.

13. See, for example, Stauffer, Trodd, and Bernier, Picturing Frederick Douglass; also see the essays collected in Pictures and Power: Imaging and Imagining Frederick Douglass (1818-2018), ed. CelesteMarie Bernier and Bill E. Lawson (Liverpool: Liverpool University Press, 2017). Two excellent essays on Douglass and photography appear in Pictures and Progress: Early Photography and the Making of African American Identity, ed. Maurice O. Wallace and Shawn Michelle Smith (Durham: Duke University Press, 2012): Laura Wexler's “'A More Perfect Likeness': Frederick Douglass and the Image of the Nation" (18-39) and Ginger Hill's “'Rightly Viewed': Theorization of Self in Frederick Douglass's Lectures on Pictures" (41-80).

14. Wexler, “'A More Perfect Likeness," 18-39.

15. As Nell Irvin Painter observes, in the nineteenth century many people believed that photographs were, in the words of Henry David Thoreau, "an exact and accurate description of facts." Yet photography "is a sign system and has its own rhetorics of representation"; therefore it could be manipulated like any other sign system. See "Representing Truth: Sojourner Truth's Knowing and Becoming Known," Journal of American History 81, no. 2 (1994): 486.

16. Tina Campt, Image Matters: Archive, Photography, and the African Diaspora in Europe (Durham: Duke University Press, 2012), 17.

17. Janet Neary, Fugitive Testimony: On the Visual Logic of Slave Narratives (New York: Fordham University Press, 2016), 27.

18. See, for example, a daguerreotype of Douglass, circa 1848, presented to Susan B. Anthony by Douglass in the Albert Cook Myers Collection, Chester County Historical Society, West Chester, PA.

19. See the photographs in Stauffer, Trodd, and Bernier, eds. Picturing Frederick Douglass, 13, 14, $15,16,17,22$, and 23.

20. Bernier and Lawson, Introduction, Pictures and Power, 31.

21. Ariella Azoulay, The Civil Contract of Photography (New York: Zone, 2008), 86.

22. Frederick Douglass, "The Meaning of July Fourth for the Negro. A speech given at Rochester, New York, July 5, 1852," https://masshumanities.org/wp-content/uploads/2019/10/ speech_complete.pdf <accessed July 21, 2020>.

23. Frederick Douglass, "Pictures and Progress," in Picturing Frederick Douglass, ed. Stauffer, Trodd, and Bernier, 166.

24. Ibid., 171.

25. See image in Stauffer, Trodd, and Bernier, eds., Picturing Frederick Douglass, 16, 19.

26. Azoulay, Civil Contract, 14.

27. All quotes from Frederick Douglass, "Oration in Memory of Abraham Lincoln," April 14, 1876, in Lift Every Voice: African American Oratory, 1787-1900, ed. Philip Sheldon Foner and Robert J. Branham (Tuscaloosa: University of Alabama Press, 1998), 570-71.

28. See Roland Barthes, Camera Lucida: Reflections on Photography, trans. Richard Howard (New York: Hill and Wang, 1981), 32.

29. Shawn Michelle Smith, At the Edge of Sight: Photography and the Unseen (Durham, Duke University Press, 2013), 190. 
30. Frederick Douglass, "Age of Pictures," 1862, in Picturing Frederick Douglass, ed. Stauffer, Trodd, and Bernier, 142.

31. See image in Stauffer, Trodd, and Bernier, eds., Picturing Frederick Douglass, 65.

32. Azoulay, Civil Contract, 312.

33. Sojourner Truth, Narrative of Sojourner Truth; a Bondswoman of Olden Time, Emancipated by the New York Legislature in the Early Part of the Present Century; with a History of Her Labors and Correspondence, Drawn from Her "Book of Life" (Boston: 1875), 140-41, Internet Archive, https:// archive.org/details/narrativeofsojou7231gilb <accessed July 1, 2021>.

34. Darcy Grimaldo Grigsby, Enduring Truths: Sojourner's Shadows and Substance (Chicago: University of Chicago Press, 2015), 28-29.

35. Painter, "Representing Truth," 482-83. Because cartes-de-visite were much cheaper to produce than daguerreotypes, they became the most popular form of photographic portrait in the early 1860s.

36. Azoulay, Civil Contract, 18 and 22.

37. Campt, Image Matters, 9.

38. Azoulay, Civil Contract, 143.

39. Painter, "Representing Truth," 485.

40. See, for example, the 1864 photograph of Truth on the Metropolitan Museum of Art's website, https://www.metmuseum.org/art/collection/search/301989 <accessed July 1, 2021>.

41. See, for example, the 1882 captioned cabinet photographs of Truth by Croydon C. Randall found in Grigsby, Enduring Truth, 181.

42. Thierry Groensteen, The System of Comics, trans. Bart Beaty and Nick Nguyen (Jackson: University of Mississippi Press, 2007 [1999]), 128.

43. Painter takes this as the overt meaning; she argues that the motto "explains the photograph's fund-raising function"; see "Representing Truth," 485.

44. Augusta Rohrbach, "Shadow and Substance: Sojourner Truth in Black and White," in Pictures and Progress, ed. Wallace and Smith, 96.

45. Painter, "Representing Truth," 462.

46. Moten, In the Break: The Aesthetics of the Black Radical Tradition (Minneapolis: University of Minnesota Press, 2003), 210 and 205.

47. See "Gordon as he entered our lines" (1863), https://www.loc.gov/resource/cph.3b44593/ <accessed July 1, 2021>; and "Wilson Chinn, a branded slave from Louisiana" (1863), https:// www.loc.gov/resource/ppmsca.57689/ <accessed July 1, 2021>.

\section{ABSTRACTS}

Invisibilization has been theorized as a mode of disempowerment, yet for African Americans who have been hypervisualized it can become a locus of social or visual power. This article examines photographic portraits of Frederick Douglass and Sojourner Truth to show how they perform versions of their identities. Via curation of objects, expressions, and slogans within the photographic mise-en-scène, Douglass and Truth create a visual avatar, while the "real" individual is strategically invisibilized by layers of disguise, manipulation, and performance. In so doing, they ask the viewer to question visuality and whether photography captures reality. 
INDEX

Keywords: slavery, photography, Frederick Douglass, Sojourner Truth, visuality

\section{AUTHOR}

\section{MARTHA J. CUTTER}

Martha J. Cutter is a professor of English and Africana Studies at the University of Connecticut. Her most current book is The Many Resurrections of Henry Box Brown, the Man who Mailed himself from Slavery to Freedom (forthcoming, U. of Penn Press, 2022). In 2017 she was the author of The Illustrated Slave: Empathy, Graphic Narrative, and the Visual Culture of the Transatlantic Abolition Movement, 1800-1852 (University of Georgia Press, August 2017). She also has published three other books as well as over forty essays or book chapters on multi-ethnic US literature, racial passing, slavery and abolition, and African American literature.

University of Connecticut 